\title{
Effects of some anti-histamine on erythrocyte aspartate amino transferase and alanine amino transferase activities in
} Wistar albino rats

\author{
B. Okwandu Ngozika ${ }^{1 *}$, C. Monago comfort ${ }^{2}$, A. Uwakwe Austin ${ }^{2}$, J. Ifemeje Chineye ${ }^{3}$ and U. Okeke Chukwubuike ${ }^{4}$ \\ ${ }^{1}$ Department of Biochemistry, Madonna University Elele Campus, Nigeria. \\ ${ }^{2}$ Department of Biochemistry, University of Port Harcourt Choba, Nigeria. \\ ${ }^{3}$ Department of Biochemistry, Anambra State University Uli, Nigeria. \\ ${ }^{4}$ Department of Prosthesis and Orthopedic Technology, School of Health Technology Federal University of
}

Technology, Owerri Nigeria.

Barthyzika@yahoo.com.au

\begin{abstract}
The present study was conducted on the rat population of animal house in Madonna University, Elele Campus, Nigeria to evaluate the status of some biochemical parameters of rats administered with varied concentrations of chlorpheniramine maleate (piriton), cyproheptadine hydrochloride (cypron), and clemastine fumarate (tavagyl). Blood samples and liver organ were collected from 51 male and female albino rats, 48 were given different concentrations of each of the antihistamine drugs for 30 days, while 3 rats were used as control. Alanine amino transferase (ALT) activity and Aspartate amino transferase (AST) were lower in the control group compare to the groups administered with piriton, Cypron, and Tavagyl at $0.04 \mathrm{mg} / \mathrm{ml}, 0.02 \mathrm{mg} / \mathrm{ml}, 0.01 \mathrm{mg} / \mathrm{ml}$, and $0.005 \mathrm{mg} / \mathrm{ml}$. From the above results it is concluded that piriton, cypron, and Tavagyl increased the activities of AST and ALT enzymes.
\end{abstract}

Keyword: Alanine amino transferase, Aspartate amino transferase, piriton, cypron, and Tavagyl, Rat.

\section{Introduction}

Anti-histamines are drugs that inhibit the action of histamine in the body by binding onto the histamine receptors (Kemp, 1992). Anti-histamines act upon the $\mathrm{H} 1, \mathrm{H} 2, \mathrm{H} 3$, and $\mathrm{H} 4$ histamine receptor. While first generation $\mathrm{H} 1$ - receptor antagonists are responsible for vast majority of poisoning, all antihistamine classes have been associated with serious toxicity.

All HI histamine antagonists are reversible competitive inhibitors of histamine receptors. First generation $\mathrm{HI}$ receptors blockers also are potent competitive inhibitors of muscarinic receptors and may cause anti-cholinergic syndrome. In addition, antihistamine disrupt cortical neurotransmission and block fast sodium channels (Leurs et al., 2000). Some nonsedating anti-histamines are known to inhibit the potassium rectifier currents which show repolarization.

$\mathrm{H} 2$ - receptor antagonists are primarily regulators of gastric acid secretion in the CNS. Histamine $(\mathrm{H} 1, \mathrm{H} 2)$ modulates activities such as arousal, thermoregulation, neuroendocrine and vegetative functions. H2 receptor antagonist is considered relatively benign in overdose. $\mathrm{H} 2$-receptor antagonist also inhibits hepatic oxidative metabolism by most cytochrome P450 enzymes and, thus the metabolism of a variety of drugs.

$\mathrm{H} 3$ - receptors are presynaptic regulators of synthesis and release of histamine into the synapses (Benett et al., 2003). Some side effects of antihistamine include sedation, drowsiness, headache, difficult in passing urine, dry mouth, blurred vision, feeling sick or vomiting, constipation or diarrhea, irritation, arrhythmia, High blood pressure, allergic reactions, dizziness, confusion, depression, disturbed sleep etc (Baker et al., 2003).
Chlorpheniramine maleate commonly called piriton is a first generation alkylamine antihistamine used in the prevention of the symptoms of allergic conditions (Katzung, 2007). It prevents histarmine from reaching its site of action and it also crosses the blood-brain barrier of effected $\mathrm{H} 1$ receptors in the brain thereby inducing sedation (Mustapha, 2008).

Chlorpheniramine works as a serotoninnorepinephrine reuptake inhibitor (Rieveschl \& Macchi, 2000). Chlorpheniramine is often combined with phenylpropanolamine to form allergy medication with both antihistamine and decongestant properties (Wilkinson et al., 1999).

Cyproheptadine hydrochloride commonly called cypron is an anti-histamine/anti-chlonergic and antiserotonergic agent (Katzung, 2007). Cyproheptadine has showed effectiveness in the treatment of nightmares, management of moderate to severe cases of serotonin syndrome and in the disease carcinoid in which sorotonin is over produced by tumour cells. It blocks the sensitizing action of serotonin on body cells and hence reduces the allergic reaction like itching (Mustapha, 2008).

Cyproheptadine when used in conjunction with oral potassium salt can cause lowing of GIT transit and increase the local exposure to high potassium concentration (Ashton et al., 2003).

Clemastine fumarate commonly called Tavagyl belongs to the benzhydryl ether group of anti-histamine compounds. Clemastine is an anti-histamine with anticholinergic and sedative side effects. It antagonizes the increase of capillary permeability that occurs in histamine release and it also inhibits the constrictor effect of histamine on respiratory muscle (Mustapha, 2008).
Research article

CIndian Society for Education and Environment (iSee)
"Effects of anti-histamine drugs" http://www.indjst.org
B.O.Ngozika et al. Indian J.Sci.Technol. 
Clemastine are indicated for the relief of symptoms associated with allergic rhinitis such as sneezing, pruritus and also indicated for the relief of mild, uncomplicated allergic skin manifestation of urticaria (Mustapha, 2008).

Materials and methods

For this study a total of 51 Wister albino rats (Rattus rattus) were used and were obtained and housed at the animal house of Madonna University Elele Nigeria during year 2010. The feed used for the rats was the normal rat chow processed by Vital Feed Limited and purchased freshly from Owerri town market in Imo State, Nigeria during the year 2010 . The rats were housed in 25 cages labeled P1, P2, P3, P4, C1, C2, C3, C4, T1, T2, T3, T4 and control. Each cage contains 4 rats, while the control cage contains 3 rats. Rats in cage $P, C$, and T were administered with varied concentrations of piriton, cypron and tavagyl respectively for a period of 30 days. Four different concentrations of piriton, cypron and Tavagyl were made from a stock of $8 \mathrm{mg} / 100 \mathrm{ml}$. Rats in cage $\mathrm{P} 1$, $\mathrm{P} 2, \mathrm{P} 3$, and P4 were administered with $0.04 \mathrm{mg} / \mathrm{ml}, 0.02$ $\mathrm{mg} / \mathrm{ml}, 0.01 \mathrm{mg} / \mathrm{ml}$, and $0.005 \mathrm{mg} / \mathrm{ml}$ piriton respectively for 30 days. Rats in cage $\mathrm{C} 1, \mathrm{C} 2, \mathrm{C} 3$, and $\mathrm{C} 4$ were also administered $0.04 \mathrm{mg} / \mathrm{ml}, 0.02 \mathrm{mg} / \mathrm{ml}, 0.01 \mathrm{mg} / \mathrm{ml}$, and $0.005 \mathrm{mg} / \mathrm{ml}$ cypron respectively for 30 days. Rats in cage $\mathrm{T} 1, \mathrm{~T} 2, \mathrm{~T} 3$, and $\mathrm{T} 4$ were administered $0.04 \mathrm{mg} / \mathrm{ml}$, $0.02 \mathrm{mg} / \mathrm{ml}, \quad 0.01 \mathrm{mg} / \mathrm{ml}$, and $0.005 \mathrm{mg} / \mathrm{ml}$ tavagyl respectively for 30 days.

At the end of 30 days of drug administration, the rats were sacrificed and blood collected by commercially available $2 \mathrm{ml}$ disposable syringes. The blood was stored in lithium heparin anticoagulant bottles. Then the samples were transported to the laboratory for further investigations. Samples were washed several times using $0.9 \mathrm{~g} / \mathrm{l}$ sodium chloride and hemolysate was collected and stand at $-2^{0 \mathrm{c}}$ before test. Erythrocyte Alanine amino transferase and aspartate amino transferase activities were determined by Reitman, and Frankel method (1957) using enzyme kit obtained from Randox laboratories United Kingdom. The test was performed according to the manufacturer's instructions. Optical density (OD) value was recorded in a digital UV Spectrophotometer at 540nm.

\section{Results}

The present study was carried out on Wistor albino rats administered with varied concentrations of piriton, cypron, and tavagyl to study the status of erythrocyte alanine amino transferase and aspartate amino transferase. The erythrocyte alanine amino transferase activity was found to be lower in the control group $(122.40 \pm 0.06 \mathrm{u} / \mathrm{l}$ than in the group administered piriton at $0.005 \mathrm{mg} / \mathrm{ml} \quad(148.80 \quad \pm 0.06 \mathrm{u} / \mathrm{l}), \quad 0.01 \mathrm{mg} / \mathrm{ml} \quad(139.00$ $\pm 0.01 \mathrm{u} / \mathrm{ml}), 0.02 \mathrm{mg} / \mathrm{ml}(128.35 \pm 0.03 \mathrm{u} / \mathrm{l})$, and $0.04 \mathrm{mg} / \mathrm{ml}$ $(124.95 \pm 0.03 \mathrm{u} / \mathrm{l})$. The aspartate amino transferase was also found to be lower in the control group (199.80 $\pm 0.03 \mathrm{u} / \mathrm{l}$ than in the group administered piriton at $0.005 \mathrm{mg} / \mathrm{ml} \quad(224.40 \pm 0.03 \mathrm{u} / \mathrm{l}), \quad 0.01 \mathrm{mg} / \mathrm{ml} \quad(231.60 \pm$
$0.06 \mathrm{u} / \mathrm{l}), \quad 0.02 \mathrm{mg} / \mathrm{ml} \quad(248.80 \pm 0.06 \mathrm{u} / \mathrm{l})$, and $\quad 0.04 \mathrm{mg} / \mathrm{ml}$ $(252.00 \pm 0.01 \mathrm{u} / \mathrm{l})$.

The erythrocyte alanine amino transferase activity was found to be lower in the control group $(122.40 \pm 0.06$ $\mathrm{u} / \mathrm{l})$ than in the group administered cypron at $0.005 \mathrm{mg} / \mathrm{ml}$ $(127.50 \pm \quad 0.03 \mathrm{u} / \mathrm{l}), \quad 0.01 \mathrm{mg} / \mathrm{ml}(137.70 \pm 0.06 \mathrm{u} / \mathrm{l})$, $0.02 \mathrm{mg} / \mathrm{ml} \quad(178.20 \pm \quad 0.06 \mathrm{u} / \mathrm{l})$, and $0.04 \mathrm{mg} / \mathrm{ml}$ $(196.05 \pm 0.03 \mathrm{u} / \mathrm{l})$.

The Aspartate amino transferase was also found to be lower in the control group $(199.80 \pm 0.03 \mathrm{u} / \mathrm{l})$, than in the group administered cypron at $0.005 \mathrm{mg} / \mathrm{ml} \quad(248.40$ $\pm 0.06 \mathrm{u} / \mathrm{l}), \quad 0.01 \mathrm{mg} / \mathrm{ml} \quad(262.80 \quad \pm 0.06 \mathrm{u} / \mathrm{l}), \quad 0.02 \mathrm{mg} / \mathrm{ml}$ $(298.00 \pm 0.01)$, and $0.04 \mathrm{mg} / \mathrm{ml}(252.00 \pm 0.01 \mathrm{u} / \mathrm{l})$.

The erythrocyte alanine amino transferase activity was found to be lower in the control group $(122.40 \pm 0.06 \mathrm{u} / \mathrm{l})$, than in the group administered tavagyl at $0.005 \mathrm{mg} / \mathrm{ml}$ $(146.20 \quad \pm 0.06 \mathrm{u} / \mathrm{l}), \quad 0.01 \mathrm{mg} / \mathrm{ml} \quad(133.10 \pm 0.06 \mathrm{u} / \mathrm{l})$, $0.02 \mathrm{mg} / \mathrm{ml} \quad(127.70 \pm 0.06 \mathrm{u} / \mathrm{l}), \quad$ and $\quad 0.04 \mathrm{mg} / \mathrm{ml}$ $(124.95 \pm 0.03 \mathrm{u} / \mathrm{l})$. The Aspartate amino transferase was also found to be lower in control group $(199.80 \pm 0.03 \mathrm{u} / \mathrm{l})$ than in the group administered tavagyl at $0.005 \mathrm{mg} / \mathrm{ml}$ $(250.20 \pm 0.06 \mathrm{u} / \mathrm{l}), 0.01 \mathrm{mg} / \mathrm{ml}(253.80 \pm 0.06 \mathrm{u} / \mathrm{l}), 0.02 \mathrm{mg} / \mathrm{ml}$ $(264.60 \pm 0.06 \mathrm{u} / \mathrm{l})$, and $0.04 \mathrm{mg} / \mathrm{ml}(246.60 \pm 0.06 \mathrm{u} / \mathrm{l})$.

The technique used for the in vitro assay is based on the original method of Reitman and Frankel (1957) and reagent 1 containing phosphate buffer, l-aspartate, and $\alpha$ oxoglutarate was used as substrate for AST while reagent 1 containing phosphate buffer, I-alanine, and $\alpha$ oxoglutarate was used as substrate for ALT. Four serial dilutions of each of the drugs were prepared (piriton: 0.00 , $0.04,0.02,0.01$, and $0.005 \mathrm{mg} / 100 \mathrm{ml}$. cypron: $0.00,0.04$, $0.02,0.01$, and $0.005 \mathrm{mg} / 100 \mathrm{ml}$. Tavagyl: $0.00,0.04$, $0.02,0.01$, and $0.005 \mathrm{mg} / 100 \mathrm{ml}$ ). Exactly $0.5 \mathrm{ml}$ of buffer substrate $\mathrm{pH} 9.8$ and $0.1 \mathrm{ml}$ erythrocyte was introduced into each of labeled four tubes including the control tube. The blank tube contains only $0.5 \mathrm{ml}$ buffer substrate. Both tubes were incubated at $37^{\circ \mathrm{c}}$ for exactly 30 minutes. $0.2 \mathrm{ml}$ of each antihistamine drug preparation was introduced into the buffer except the control tube in which case is added $0.2 \mathrm{ml}$ of water. The tubes were mixed and left in the incubator for 15 minutes. $0.5 \mathrm{ml}$ of reagent $2(2,4-$ dinitrophenylhydrazine) was added into each tube and further incubated for 10 minutes at $37^{\circ \mathrm{c}} .5 \mathrm{ml}$ of $0.4 \mathrm{mmol} / /$ sodium hydroxide was finally added into each tube. The absorbance of test and control was read against the blank within 5 minutes with UV Spectrophotometer.

\section{Discussion}

Various blood biochemical parameters were studied to evaluate the effect of chlorpheniramine maleate (piriton), cyproheptadine hydrochloride (cypron), and Clemastine fumarate (Tavagyl) on amino rats.

The in vivo and in vitro studies showed that the activities of erythrocyte AST and ALT increased in presence of the three anti-histamine drugs after 30 days. In one of the reactions of amino acid metabolism (Transamination), AST transferes amino group from $\alpha$ amino acid (glutamate) to $\alpha$ - keto acid (oxaloacetate) to
Research article

(C)Indian Society for Education and Environment (iSee)
"Effects of anti-histamine drugs" http://www.indjst.org
B.O.Ngozika et al. Indian J.Sci.Technol. 
Table 1. In vivo Erythrocyte ALT and AST in control group and group administered different concentrations of piriton

\begin{tabular}{|c|c|c|c|}
\hline \multirow{2}{*}{ Antihistamine } & $\begin{array}{c}\text { concentrations } \\
(\mathrm{mg} / \mathrm{ml})\end{array}$ & \multicolumn{2}{|c|}{ Mean \pm SD } \\
\cline { 2 - 4 } & 0.00 & $\mathrm{ALT} \mathrm{u} / \mathrm{l}$ & $\mathrm{AST} \mathrm{u} / \mathrm{l}$ \\
\hline \multirow{4}{*}{ Piriton } & 0.04 & $122.40 \pm 0.06$ & $199.80 \pm 0.03$ \\
\cline { 2 - 4 } & 0.02 & $139.80 \pm 0.06$ & $224.40 \pm 0.06$ \\
\cline { 2 - 4 } & 0.01 & $128.35 \pm 0.03$ & $231.80 \pm 0.06$ \\
\cline { 2 - 4 } & 0.005 & $124.95 \pm 0.03$ & $248.80 \pm 0.06$ \\
\hline
\end{tabular}

Table 2. In vivo Erythrocyte ALT and AST in control group and group administered different concentrations of cypron

\begin{tabular}{|c|c|c|c|}
\hline \multirow{2}{*}{ Antihistamine } & $\begin{array}{c}\text { concentration } \\
\mathrm{s}(\mathrm{mg} / \mathrm{ml})\end{array}$ & \multicolumn{2}{|c|}{ Mean \pm SD } \\
\cline { 2 - 4 } Cypron & 0.00 & ALT u/l & AST $\mathrm{u} / \mathrm{l}$ \\
\hline & 0.04 & $122.40 \pm 0.06$ & $199.80 \pm 0.03$ \\
\cline { 2 - 4 } & 0.02 & $137.50 \pm 0.03$ & $248.40 \pm 0.06$ \\
\cline { 2 - 4 } & 0.01 & $178.20 \pm 0.06$ & $262.80 \pm 0.06$ \\
\cline { 2 - 4 } & 0.005 & $196.05 \pm 0.03$ & $298.00 \pm 0.01$ \\
\hline
\end{tabular}

Table 3. In vivo Erythrocyte ALT and AST in control group and group administered different concentrations of Tavagyl

\begin{tabular}{|c|c|c|c|}
\hline \multirow{2}{*}{ Antihistamine } & $\begin{array}{c}\text { concentrations } \\
(\mathrm{mg} / \mathrm{ml})\end{array}$ & \multicolumn{2}{|c|}{ Mean \pm SD } \\
\cline { 2 - 4 } & 0.00 & $122.40 \pm 0.06$ & $199.80 \pm 0.03$ \\
\hline \multirow{4}{*}{ Tavagyl } & 0.04 & $146.20 \pm 0.06$ & $250.20 \pm 0.06$ \\
\cline { 2 - 4 } & 0.02 & $133.20 \pm 0.06$ & $253.80 \pm 0.06$ \\
\cline { 2 - 4 } & 0.01 & $127.70 \pm 0.06$ & $246.60 \pm 0.06$ \\
\cline { 2 - 4 } & 0.005 & $124.95 \pm 0.03$ & $246.60 \pm 0.06$ \\
\hline
\end{tabular}

Table 4. In vitro Erythrocyte ALT and AST in control group and group administered different concentrations of Piriton

\begin{tabular}{|c|c|c|c|}
\hline \multirow{2}{*}{ Antihistamine } & $\begin{array}{c}\text { concentratio } \\
\text { ns (mg/ml) }\end{array}$ & \multicolumn{2}{|c|}{ mean \pm SD } \\
\cline { 2 - 4 } & 0.00 & $23.02 \pm 31$ & $47.00 \pm 0.55$ \\
\hline \multirow{4}{*}{ Piriton } & 0.04 & $23.90 \pm 0.50$ & $49.50 \pm 0.22$ \\
\cline { 2 - 4 } & 0.02 & $23.90 \pm 0.47$ & $49.80 \pm 0.38$ \\
\cline { 2 - 4 } & 0.01 & $32.90 \pm 0.28$ & $55.50 \pm 0.55$ \\
\cline { 2 - 4 } & 0.005 & $43.40 \pm 0.41$ & $67.10 \pm 0.42$ \\
\hline
\end{tabular}

Table 5. In vitro Erythrocyte ALT and AST in control group and group administered different concentrations of cypron

\begin{tabular}{|c|c|c|c|}
\hline \multirow{2}{*}{ Antihistamine } & $\begin{array}{c}\text { concentrations } \\
(\mathrm{mg} / \mathrm{ml})\end{array}$ & \multicolumn{2}{|c|}{ mean \pm SD } \\
\cline { 2 - 4 } & 0.00 & $23.02 \pm 0.31$ & $47.00 \pm 0.55$ \\
\hline \multirow{4}{*}{ Cypron } & 0.04 & $23.27 \pm 0.57$ & $49.10 \pm 0.42$ \\
\cline { 2 - 4 } & 0.02 & $26.47 \pm 0.64$ & $49.40 \pm 0.55$ \\
\cline { 2 - 4 } & 0.01 & $26.47 \pm 0.51$ & $55.20 \pm 0.42$ \\
\cline { 2 - 4 } & 0.005 & $36.83 \pm 0.38$ & $59.50 \pm 0.42$ \\
\hline
\end{tabular}

Table 6. In vitro Erythrocyte ALT and AST in control group and group administered different concentrations of Tavagyl.

\begin{tabular}{|c|c|c|c|}
\hline \multirow{2}{*}{ Antihistamine } & $\begin{array}{c}\text { concentrations } \\
(\mathrm{mg} / \mathrm{ml})\end{array}$ & \multicolumn{2}{|c|}{ mean \pm SD } \\
\cline { 2 - 4 } & 0.00 & ALT u/l & AST u/l \\
\hline \multirow{4}{*}{ Tavagyl } & 0.04 & $31.02 \pm 0.31$ & $47.00 \pm 0.55$ \\
\cline { 2 - 4 } & 0.02 & $30.02 \pm 0.55$ & $49.10 \pm 0.55$ \\
\cline { 2 - 4 } & 0.01 & $34.53 \pm 0.75$ & $57.50 \pm 0.55$ \\
\cline { 2 - 4 } & 0.005 & $46.04 \pm 0.25$ & $69.20 \pm 0.55$ \\
\cline { 2 - 4 } & &
\end{tabular}


form an $\alpha$ - amino acid (Aspartate) while ALT transfers amino group from $\alpha$-amino acid (glutamate) to - keto acid (pyruvate) to form an $\alpha$ - amino acid (alanine). The increase in AST and ALT suggested the activatory ability of the drugs to the activities of the enzymes. It therefore suggested that the drugs have no binding effect on the active sites of the enzymes; rather they may have acted as a cofactor to the enzymes, speeding up the transamination reaction.

The dose dependent activatory effect of piriton, cypron and Tavagyl on erythrocyte AST and ALT activities could possibly result from electrostatic and hydrogen binding interactions between the drug and amino acid residue at the active site. High levels of AST and ALT induced by the drugs could be a consequence of hepatocellular and cardiac toxicity (Whitby et al., 1980).

The activation of AST and ALT could promote transport of amino group across the cell membrane. AST and ALT are used as a marker for liver disease with ALT being more specific and myocardial infarction with AST being more specific (Tietz, 1986). The non concentration dependent increase in AST and ALT observed in some cases could be attributed to clinical limitations, technical limitations, disorders in the drug, absorption, bioavailability of the drug, biotransformation of the drug, and influence of drug metabolizing enzymes in the liver microsomes. AST and ALT are synthesized by the cells in response to any form of biliary obstruction and myocardium disorder. Some of the newly formed enzymes enter into the blood circulation and raise the level. This could be the possible cause of the observed rise in the level of AST and ALT activity. The rise in AST and ALT activities could also be as a result of the drugs causing high proliferation of liver and heart cells, low rate of enzymes clearance from circulation caused by the drugs and a high degree of induction of enzyme synthesis caused by the drugs.

\section{References}

1. Ashton AK and Weinstein WL (2003) Cyproheptadine for drug-induced sweating. Am. J. Psychiatry.159, 874-875.

2. Baker AM, Johnson DG and Levisky JA (2003) Fatal diphehydramine intoxication in infants. J. Forensic Sci. 48(2), 425-428.

3. Benett RN and Brown MJ (2003) Clinical Pharmacolgy. $9^{\text {th }}$ Ed., Elsevier Sci. Ltd: pp: 67-69.

a. Katzung BG (2007) Basic and clinical pharmacology. $\left(10^{\text {th }}\right.$ ed.) Mc Graw - Hill Companies, Singapore. pp: 930

4. Kemp JP (1992) Antihistamines: is there anything safe to prescribe? Ann. Allergy. 69, 276-280.

5. Leurs R, Church MK and Taglialatela M (2000) H antihistamines: inverse agonism, anti-inflammatory action and cardiac effects. Clin. Expressed Allerge. 32, 489-498.
Vol. 5 No. 6 (June 2012)

ISSN: 0974- 6846

6. Mustapha RO (2008) Easier approach to pharmacology for all health professionals $\left(2^{\text {nd }}\right.$ ed. $)$ Adewumi printing press, Nigeria. pp: 121-124.

7. Reitman S and Frankel S (1957) A colorimetric method for the determination of serum glutamic oxalacetic and glutamic pyruvic transaminases. $A m$. J. Clin. Pathol. 28, 56-63.

8. Rieveschl R and Macchi G (2000) Cyproheptadine for posttraumatic Nightmare. Am. J. Psychiatry. 157, 1524-1526.

9. Tietz NW (1986) Fundamentals of clinical chemistry .W.B. Saunders co. Philadelphia, P.A. pp: 669-678.

10.Whitby LG, Percy, Rooby, W and Smith AF (1980) Lecture notes on clinical chemistry $2^{\text {nd }}$ ed. Black wel Sci. Publ., London pp: 100-225.

11.Wilkinson GR and Beckett AM (1999) Influence of urine $\mathrm{PH}$ and flow rate on renal excretion of chlorpheniramine maleate. J. Pharmacol. pp: 17-25
"Effects of anti-histamine drugs" http://www.indjst.org
B.O.Ngozika et al. Indian J.Sci.Technol. 